\begin{abstract}
Richard Hörmann*
Salzburg

\section{Słowo myślane, pisane i mówione. Ferdinand Ebner w swoich listach do Luizy Karpischek}

W traktatach filozoficznych mamy do czynienia z reguły z wywodami, które stosują się do pewnej konwencji, mają swoją gotową formę logiczną, ale poruszają się na pewnym poziomie ogólności, są wyabstrahowane i oderwane od życia, z którego się zrodziły. Fakt ten postrzegany jest przeważnie jako sytuacja normalna i pożądana: słowo abstrakcyjne dyskutuje ze słowem abstrakcyjnym na jakimś abstrakcyjnie wyznaczonym polu, kierując się abstrakcyjnie wyznaczonymi regułami, które muszą być spełnione przez stosowane argumenty. Im bardziej abstrakcyjne jest to słowo, im bardziej oderwane od życia - tym lepiej, bo dzięki temu jest ogólniejsze i lepiej opisuje „wszechświat”. Ale czy ten wszechświat ma jeszcze coś wspólnego z rzeczywistością? Z życiem? Czy sam nie jest już tylko abstrakcyjną ideą? Czy za precyzję sformułowań nie płacimy „ludzką” rzeczywistością, skutecznością, „ludzkością” słowa? Czy człowiek może jeszcze jakoś „,skonsumować” z prawdziwym dla siebie pożytkiem owoce uciekającej w abstrakcję - a więc w ,nieludzkość" - nauki? Takie abstrakcyjne słowo jest krytykowane przez Ferdinanda Ebnera jako słowo martwe, a oparta na nim filozofia ma być zastąpiona przez opartą na słowie żywym ,pneumatologię”.

* Dr Richard Hörmann pracuje w Paris Lodron Universität Salzburg i działa w Międzynarodowym Towarzystwie Ferdinanda Ebnera. Adres: Internationale Ferdinand Ebner-Gesellschaft, Gries 7, A-6091 Götzens, Austria; e-mail: richard.hoermann@uibk.ac.at. 
Poglądy Ebnera można uznać za znane - a przynajmniej można je częściowo prześledzić w wydaniach jego dzieł. Ale ich rzeczywistość, ich moc i aktualność leżą w ich powiązaniu z życiem, i to życiem konkretnym, a takie zawsze wiąże się z biografią, czyli - nawiązując do sformułowań Ebnera jest w Ja, a Ja jest w kontakcie z Ty. Czy więc można wyobrazić sobie lepszą drogę do zbadania powiązań między różnymi rodzajami słowa niż na podstawie osobistej, prywatnej, czy wręcz intymnej korespondencji, gdzie nie ma już miejsca na maski, gdzie wszelka abstrakcja zostaje odrzucona? Widzimy tu także skuteczność słowa w spotkaniu międzyludzkim i jałowość słowa martwego, pustego, abstrakcyjnego, niebudującego relacji, pogłębiającego tylko samotność. Oczywiście, cała twórczość Ebnera czerpie swą energię z tego właśnie napięcia i może być widziana jako próba przezwyciężenia tej sprzeczności.

Zostaje tu więc podjęta - mówiąc banalnie - próba połączenia poglądów filozoficznych Ferdinanda Ebnera z jego życiem prywatnym. Pośrednikiem - i naszym przewodnikiem - będzie oczywiście słowo w swych różnych wcieleniach. Ciekawą rzeczą byłoby prześledzenie drogi, jaką przechodzi słowo od życia (wyrażającego się w spotkaniach międzyludzkich) do zainspirowanej nim myśli (do której nie mamy de facto dostępu z zewnątrz) i dalej poprzez jej sformułowanie (w słowie, w piśmie, dla siebie, dla drugiego), z powrotem do życia, by je przemieniać. Celem naszych rozważań, podyktowanych już samym rozmiarem tej pracy, jest jednak - bardziej niż szczegółowe wyjaśnienie tego procesu - dostarczenie impulsów do osobistego namysłu. Dlatego też wiele wątków zostaje dotkniętych, ale nie są one rozwijane.

W ramach spuścizny pisarskiej Ferdinanda Ebnera znajduje się obok jego dzieł filozoficznych i licznych dzienników także obfita korespondencja, obejmująca około 1400 listów. Większość z nich adresowana jest do Luizy Karpischek, nauczycielki zajęć praktycznych w mieście Wiener Neustadt, która była przyjaciółką z lat dziecięcych siostry Ebnera, Marii. Od początku ich znajomości, zawartej wiosną 1900 roku, Ebner prowadził z Luizą ożywioną wymianę listów, której intensywność była szczególnie wysoka w czasie I wojny światowej, pomiędzy latami 1914 i 1918, i wynosiła nawet kilka listów na tydzień. Wymiana ta traci wyraźnie na intensywności dopiero we wczesnych latach dwudziestych, gdy Ebner intensyfikuje swoją znajomość z koleżanką z grona nauczycielskiego szkoły w Gablitz, Marią Mizerą, z którą zawiera w roku 1923 związek małżeński. Od roku 1924, za wyjątkiem kilku listów w ostatnich latach życia Ebnera, wymiana listów między nim a Luizą Karpischek zamiera całkowicie. 
Z tego zbioru listów chcę teraz spróbować wydobyć pewne charakterystyczne cechy i na podstawie cytatów przedstawić pewne treści, które Ebner przekazywał swej korespondencyjnej przyjaciółce. Pod względem formy listy wykazują pewien zauważalny porządek. Ebner pisze albo na dwu- lub nawet czterostronicowych arkuszach papieru, albo wysyła karty pocztowe. Arkusze zostają z reguły zapisane całkowicie, a jeśli miejsce nie zostaje wykorzystane do końca, Ebner przeprasza za to. Gdy chodzi o długość listów, wystarcza przeważnie jeden arkusz, tylko niektóre z nich rozszerzają się na dwa arkusze. Karty pocztowe pisze Ebner, gdy brakuje mu czasu na wyczerpujące relacje albo gdy nie ma na nie siły, za co także przeprasza. Budowa listów jest wszędzie taka sama: na początku znajduje się po prawej stronie miejscowość, w której Ebner akurat przebywa, oraz data. Następnie mamy zwrot „Droga Luizo” (Liebe Luise) oraz tekst. Na końcu stoi proste „F”, często uzupełnione o pozdrowienie ,żegnaj” (Leb wohl). Pedantyczny porządek znajduje odzwierciedlenie także w wyglądzie pisma. Znaki napisane czarnym atramentem kurrentą rozłożone są bardzo równomiernie, linijki tekstu mimo tego, że papier nie jest liniowany, są równe jak pod lineałem. Do dobrej czytelności listów przyczynia się także Ebnerowska pewność wyrażania się i ortografii, pozwalająca mu na pisanie zdań bez późniejszych poprawek.

Miejscem powstania listów jest przeważnie Gablitz, mała miejscowość niedaleko Wiednia, gdzie Ebner uczył od roku 1912 w tamtejszej szkole podstawowej. Przez pewien czas było jego przyzwyczajeniem, że po szkole udawał się piechotą do kawiarni w sąsiedniej, nieco większej miejscowości, Purkersdorf, gdzie czytał gazety, spotykał znajomych albo też mimo zmęczenia czy złego samopoczucia znajdował koncentrację potrzebną do napisania listu do Luizy Karpischek. Także kawiarnia Cafe Akademie w Wiedniu, którą Ebner podczas swych rzadkich wypraw do miasta chętnie odwiedzał, pojawia się czasami jako miejsce powstania listu wymienione na początku tekstu.

Także odnośnie do wewnętrznej struktury korespondencji dają się stwierdzić pewne reguły. Te odnoszą się przede wszystkim do sposobu, w jaki Ebner rozpoczyna swe listy. Dwa typowe przykłady:

Droga Luizo, w ostatnią sobotę nie pamiętałem jeszcze dokładnie nowego rozkładu jazdy kolei zachodniej. Kwadrans przed piątą byłem na Dworcu Zachodnim [tzw. Westbahnhof w Wiedniu, przyp. thum.] i musiałem czekać na następny pociąg odjeżdżający kilka minut po szóstej. Byłem zbyt zmęczony, by spędzić ten czas chodząc po poczekalni, tak więc nie pozostało mi nic innego, 
jak udać się do kawiarni. A potem ta jazda do Purkersdorfu - trwała prawie tak długo jak z Neustadt do Meidling. Pierwsze dni obecnego tygodnia upłynęły jako tako. To małe pogorszenie mojego samopoczucia, które odczułem już w niedzielę w Neustadt, trochę jeszcze potrwało. Ciagle jeszcze jestem zmęczony i prawie zniechęcony. A poza tym właśnie pod koniec tygodnia gromadzą się wszystkie możliwe sprawy... (30.03.1916).

Droga Luizo, dlaczego nie mam od Ciebie już tak długo żadnych wiadomości? To już ponad tydzień, odkąd napisałem do Ciebie list, i prawie dwa tygodnie, odkąd Ty mi ostatnio napisałaś. I jako że poczta także dzisiaj nic od Ciebie nie dostarczyła, jest to dla mnie wystarczający powód, by zacząć się niepokoić. Proszę, odpowiedz mi od razu na tę kartkę, jeśli mi w międzyczasie jeszcze nic nie napisałaś. Nie jesteś, mam nadzieję, chora? Albo nie dręczą Cię jakieś inne problemy? (18.01.1917)

$\mathrm{Na}$ ile to możliwe, Ebner stara się spędzać weekendy u Luizy Karpischek w Wiener Neustadt. Jej miejsce zamieszkania oddalone jest od Gablitz o około $60 \mathrm{~km}$, ale podróż koleją jest męcząca, ponieważ Ebner musi jechać przez Wiedeń i tam się przesiadać. Do tego dochodzi fakt, że w czasie I wojny światowej połączenia na Kolei Zachodniej [linia kolejowa prowadząca z Wiednia w kierunku Salzburga, przyp. tłum.] są kiepskie, tak że odwiedziny Ebnera w Neustadt stają się rzadsze. Opowiadania o powrocie z upragnionego spotkania rozpoczynają zazwyczaj jego listy. Na życzenie Luizy i z własnej potrzeby Ebner stara się dokładnie opisać, kiedy i gdzie się znajdował.

Zamiast opowieści o podróży mamy w niektórych listach na początku także skargi Ebnera na długo oczekiwane, ale nienadchodzące reakcje Luizy Karpischek. Te wprowadzenia wyrażają troskę, czy aby z przyjaciółką cierpiącą podobnie jak on sam z powodu chorowitej natury - nie dzieje się coś złego, albo też, czy w swoich listach nie napisał czegoś, co zakłóciłoby jej chęć odpowiedzi. Radość i wdzięczność za dochodzące w końcu odpowiedzi dużo mówią o jego stosunku do Luizy Karpischek. Pewne jest, że oboje odczuwali do siebie sympatię czy wręcz miłość, chociaż w różnym stopniu. Stopień tej sympatii wydaje się podlegać wahaniom u obojga oraz być po stronie Luizy większy. W pewnym miejscu swego Pamiętnika z Mühlau, który pisał podczas pobytu u Ludwiga von Fickera w roku 1920, Ebner przyznaje się przed sobą do asymetrii w tej relacji:

W całym tym świecie, który leży obecnie za mną jako coś bardzo dalekiego i obcego, i do którego za kilka tygodni będę wracał, jest pod prawdziwie ludz- 
kim względem tylko jeden jasny punkt: L., nie mój stosunek do niej (niech niebo będzie mi łaskawe, że tak nie jest), lecz jej stosunek do mnie. Czyż nie otwierają się w nim wszystkie cuda miłości - a sama miłość jest przecież „cudem”, wielkim, niepojętym cudem naszego życia? Miłości, która ma swój ostateczny fundament w Bogu? Cóż wiedzą o tym ,antyfeminiści”! A następnie jeszcze coś - znajomość z Schachem. Także i on jest po ludzku lepszy w swym stosunku do mnie niż ja w moim do niego $(29.07 .1920)^{1}$.

Jak daleko posuwała się ta miłosna relacja i czy Luiza Karpischek była „kochaną nie tylko platonicznie”, jak pisze Franz Seyr w swej biografii Ebnera, nie da się z listów jednoznacznie wywnioskować, Ebner bowiem jest bardzo powściagliwy w opisach swoich pobytów w Wiener Neustadt ${ }^{2}$. Najbardziej bezpośrednio wyraża się w liście z 9.05.1917 r.: „A w Zielone Świątki pocałujesz mnie i wypijesz ze mną herbatę. Swoją drogą: czy nie będę mógł wybrać się do Neustadt wcześniej?"

Chociaż kontakt z Luizą Karpischek był z reguły harmonijny i serdeczny, trzeba jednak wymienić pewne jej zachowanie, które raz po raz denerwowało Ebnera. Tym, co go gniewało, były paczki z łakociami, które przesyłała mu pomimo spowodowanych wojną braków i mimo jej własnej skromnej sytuacji materialnej. Paczki te wprowadzały Ebnera w konflikty sumienia, ponieważ uważał on, że mieszkaniec miejscowości, w której czasami brakowało mąki do pieczenia chleba, nie ma prawa delektować się potrawami, o których inni mogą tylko pomarzyć. $Z$ drugiej strony jego chorowity organizm uzależniony był od tych podarunków a apetyt zbyt duży, by je odrzucić. W jego złości pobrzmiewa więc zarazem radość z paczek i z objawiającej się w nich sympatii ich nadawczyni:

Droga Luizo, mam dzisiaj dużo pracy w ramach „komisji chlebowej”, ale czasu wystarcza mi, by Ci napisać, że jestem na Ciebie zły. I muszę Ci to napisać. Jestem naprawdę zły. Nie dlatego, że nie słuchasz moich słów i nie bierzesz poważnie moich usilnych próśb - bo gdybyś je, i mnie w nich, wzięła na poważnie, nie spodziewałabyś się, że ucieszysz mnie, że tak powiem, wbrew mojej woli rzeczami, których przygotowanie i smakowanie w obecnym czasie nie jest właściwie dozwolone. Muszę być zły na Ciebie, bo nie mogę Twego postępowania uznać za właściwe i nie wolno mi tego zrobić - nawet gdy dostrzegam tę

${ }^{1}$ Ferdinand Ebner, Mühlauer Tagebuch 23.7.-28.8.1920 (Wien: Böhlau, 2001), 12.

2 Franz Seyr, „Biographie”, w: Ferdinand Ebner, Schriften, t. 2 (München: Kösel, 1963), 1115 . 
miłość, która przez nie przemawia. A widzę ją naprawdę. Jest to jednak Twoja wina, że muszę mojego serca przed nią bronić. Piec ciasta i torty i wysyłać je mi jest szaleństwem w tych czasach, szaleństwem wobec tego, co nas jeszcze czeka. Czy jesteś tego świadoma, droga Luizo? Przedwczoraj był u nas powiatowy inspektor do spraw żywności i omawiał z „komisją chlebową” konieczność ograniczenia dodatkowych kartek. A przy tym opowiadał nam, że jest po prostu za mało mąki i prawdopodobnie w czerwcu przyjdzie czas, że w ogóle nie dostaniemy chleba. Rozumiesz więc, że nie mogę się cieszyć z Twojej paczki - z taką miłością przygotowanej i mającej być dla mnie niespodzianką? Rozumiesz, że tym razem jestem naprawdę zły? ... Pogódź się ze mną, droga Luizo, przez to, że przyznasz, że tym razem nie miałaś racji. ... żegnaj. Nie ucieszy Cię ta moja kartka - ale to nie moja wina (4.06.1917).

Dla Ebnera ten osobisty kontakt z Luizą Karpischek nie był tylko sprawą prywatna, którą oddzielałby ściśle od swego filozoficznego myślenia. Luiza Karpischek była raczej tym realnym „Ty”, które potwierdzało mu jego „myśl podstawową” z Fragmentów, według której ludzkie „Ja” w sposób konieczny zależne jest w swej egzystencji od „Ty”. Poza tym znajomość z Luizą Karpischek odegrała prawdopodobnie ważną rolę w powstaniu tejże myśli. Fragment listu z 10.01.1917 roku wskazuje na to wyraźnie: „A teraz jestem bardzo szczęśliwy, szczęśliwy jak rzadko kiedy, bo znowu porozmawiałem z Tobą. Tak jakbyś siedziała obok mnie. Jesteś naprawdę całkowicie tym Ty, którego moje «samowolne» Ja poszukuje - mówiąc żargonem moich myśli z ostatnich dni".

Owo Ty, którym człowiek jest dla innego człowieka, nie jest jednak jedynym sposobem, w jaki ludzie mogą się do siebie ustosunkować. Obok relacji Ja do Ty, dokonującej się zarówno w słowie, jak i w miłości, ujawnia się stosunek Ja, który ma ono samo do siebie i w którym nie pojawia się Ty. Ta „samotność Ja” i „zamkniętość na Ty” jest, na równi z relacją do Ty, myślą, którą Ebner, jak wskazują na to listy, wziął z własnego życia i która opisuje jego doświadczenie z innymi ludźmi.

Być otoczonym ludźmi nieświadomymi - tak to właśnie ze mną jest. Od zawsze. Kiedy myślę na przykład o nieświadomości doktora Räuschera - nie, nie chcę cofać mojej drogi „rozwoju”. Bromberg, Waldegg - a teraz Gablitz - nie mogę w tym świecie czuć się jak u siebie. A co z ludźmi, którzy żyli w moim świecie? W końcu musiałem ich omijać, coraz bardziej oddalony, aż trawy wyprostują się po moich krokach i każdy ślad po przejściu zostanie zatarty. Teraz moja samotność jest całkowita - w Waldegg nie mogłem przecież przewidzieć, 
jak samotny może być człowiek. A już wtedy czułem się dość samotny. Ale teraz naprawdę dosyć (3.05.1917).

Przedwczoraj nie odbyło się to sympozjum, o którym Ci pisałem. Siedziałem całkiem sam u Klebla i nie było mi tego żal. Miałem nawet ochotę zamówić herbatę, zapaliłem sobie papierosa - ale nie z tej paczki, która obiecana jest Tobie - i byłem gotów na to, by przywrócić w sobie równowagę świata. A siedziałem przy tym w podcieniach, pod dziką winoroślą, a w górze cztery akacje. Siedzi się tam pięknie. Ale niestety szef też tak pomyślał - nikogo innego nie chciałem w tej chwili bardziej uniknąć - i przywlókł ze sobą jeszcze towarzystwo, oczywiście towarzystwo wykwintne. I koniec z wiarą w kosmos i harmonię wszechświata. Mam nadzieję i chciałbym bardzo wyrwać się stąd w niedzielę już z samego rana (2.08.1916).

Gwoli uzupełnienia mojego opowiadania: zazwyczaj żyję sobie tak, że na dobrą sprawę nic nie słyszę i nie widzę ze świata, który mnie otacza; czasami jednak zwracam na niego uwagę, albo też to on zwraca moją uwagę, ta nieszczęsna niskość i żałosność, w której ludzie tego świata spędzają swoje życie, ta straszna duchowa i moralna egzystencja bagienna, w której już choćby dlatego każda jakby wyższa forma egzystencji nie może zostać zauważona, że zakłóciłaby ona dobre samopoczucie - i wtedy reaguję bardzo łatwo pewnym dość „histerycznym" poczuciem obrzydzenia (15.03.1917).

Wieczorem spotkałem u Klebla koleżanki Wallner i Rendulic, nastrojone tak jak i ja według jakiejś tonacji molowej. A wczoraj obudziłem się ze zdecydowaną odrazą wobec tego kieratu, w którym muszę się tu ostatnio kręcić. Mojego nastroju nie polepszył też fakt, że cały dzień marzłem. Oczywiście było trochę do roboty, ale nie przeszkodziło mi to po jedzeniu uciec w sen - przed tym światem, wobec którego nie mogę się zdobyć na inne uczucie niż obrzydzenie. Dzisiaj, tej jesieni, zabrać się za jakąś pracę intelektualną - że tak powiem z czystego zwątpienia odnośnie do tego świata, w którym muszę egzystować. Bezpośrednio z mojego poczucia egzystencji przytakiwać mu i zgadzać się na niego - to nie jest dla mnie możliwe już od dłuższego czasu (17.09.1916).

Wyrażane raz po raz przygnębienie Ebnera wobec warunków jego życia w Gablitz, do których należał także brak głębszego kontaktu z mieszkańcami tej miejscowości, osiaga w niektórych listach takie natężenie, że on sam czuje się w następnym liście zmuszony zwrócić uwagę na swój zły nastrój, w którym poprzednie stwierdzenia zostały napisane, aby nie załamać Luizy 
Karpischek takim bezlitosnym przedstawieniem swego życia wewnętrznego: „Ten list z poprzedniego tygodnia, który napisałem w «przygnębionym» nastroju, musiałbym wycofać przynajmniej wewnętrznie, po tym jak przekazałem go już poczcie i przez to wycofanie zewnętrzne stało się niemożliwe. Takie listy nie powinny być pisane inaczej, jak tylko w głowie - podobnie jak Twoja na nie odpowiedź" (21.04.1915).

W porównaniu listów z pisanymi w czasach I wojny światowej pamiętnikami daje się zauważyć, że rozważania o wydarzeniach wojennych zajmują dużo więcej miejsca w pamiętnikach niż w listach. Ta nierównowaga mogła mieć kilka powodów: po pierwsze, Luiza Karpischek nie była szczególnie zainteresowana operacjami politycznymi i militarnymi, po drugie, rozmawiała o nich z Ebnerem podczas jego wizyt w Wiener Neustadt w weekendy i wspominanie o nich jeszcze raz w listach było niepotrzebne, po trzecie, Ebner nie mógł czy też nie chciał pozostawić wydarzeń wojennych bez komentarza a bał się cenzury, poszukującej nieustannie „zdrajców ojczyzny”. To, że jego korespondencja była cenzurowana, wykazuje list otrzymany od jego siostry Anny: „W domu znalazłem list z Zurychu, który cenzura trzymała przez trzy tygodnie" (11.12.1916).

Mimo oszczędnie zamieszczanych uwag na ten temat, daje się z listów wyczytać, że Ebner przechodził w czasie wojny przemianę. Na początku owa powszechna gorączka wojenna obudziła także jego niemiecko-narodowe sympatie, uśpione od czasów młodości i udokumentowane w jego spuściźnie w formie kieszonkowych kalendarzy. Austriacko-węgierskie sukcesy zostają więc przez Ebnera odnotowane z sympatia, tak jak na przykład w liście z roku 1915, w którym, swoją drogą, widać już wyraźny dystans do emocjonalnych reakcji: „Oczywiście ucieszyliśmy się bardzo wiadomościami z frontu w zachodniej Galicji. W środę nawet za bardzo - bo w szkole przejęliśmy się tymi przesadzonymi meldunkami wojennymi i przerwaliśmy, za moją radą, lekcje" (8.05.1915).

Dużo bardziej sceptyczny jest Ebner dwa lata później, gdy zdobycie Czerniowców komentuje następująco: „W Purkersdorfie usiadłem w kawiarni, wypiłem kawę z mlekiem, wypaliłem cygaro i czytałem w gazecie robotniczej o wkroczeniu naszych oddziałów do Czerniowców - co nie skłoniło mnie jednak do wewnętrznego wywieszenia flag" (5.08.1917). Wywołana przez wojnę i ciągle rosnąca bieda w jego otoczeniu, relacje $\mathrm{z}$ frontu, które zdawali mu przyjaciele, oraz lektura czasopism Fackel i Brenner, które z różniących się od siebie pozycji atakowały wojnę i jej „duchowych przywódców", wszystko to uczyniło z Ebnera zdecydowanego przeciwnika wojny i tych duchowych postaw, co do których uważał, że są one za nią odpo- 
wiedzialne. Jak mocna stała się jego awersja, widać na przykładzie reakcji na przesyłkę od jego przyjaciela z młodości, Rudolfa Bauera, który prosił Ebnera o ocenę jego dzieła literackiego:

Wspomniałem $\mathrm{Ci}$ w moim ostatnim liście, że otrzymałem znowu znak życia od Rudolfa Bauera. Już w piątek poczta dostarczyła mi manuskrypt jego „dzieła": Petnia czasu - niemiecka sztuka festiwalowa. Właściwie wystarczyło przeczytać ten tytuł, aby wiedzieć, o co chodzi. Nawet nie ciekawość, ale nuda deszczowego popołudnia, którego nie mogłem po szkole spędzić w kawiarni, spowodowała, że z braku innego pomysłu postanowiłem przeczytać całość. $\mathrm{Na}$ wykwity dyletantyzmu byłem przygotowany - ale nie na takie. Naprawdę, nawet szacunek dla dawnej znajomości nie był w stanie powstrzymać mnie od tego, by w pewnych miejscach po prostu wybuchnąć śmiechem. O Boże - jakimże nieświadomym człowiekiem może być taki gimnazjalny profesor. I na jakimże duchowym odludziu musi on żyć i czuć się tam dobrze, tak dobrze, że pisze sztuki - z poczucia pełni czasów. Oczywiście gra przy tym na uczuciach. Ale - kiedy widzę, że ktoś próbuje tak grać na uczuciach (na „niemieckich” uczuciach w tych czasach!!!), to czuję się skłonny te uczucia zaatakować. To prawda - nauczyciel szkoły średniej nie ma żadnej, absolutnie żadnej intelektualnej (duchowej) przewagi nad nauczycielem szkoły podstawowej. Nawet przewagi akademickiego wykształcenia. Nie ma bowiem sensu brać jej pod uwagę, gdy ktoś nie umie z nią począć nic lepszego, niż nauczyciel szkoły podstawowej z nędzą swego pół-wykształcenia. I ktoś taki wysyła mi swoje dzieło - mi! - do „surowej i pełnej zrozumienia” krytyki. Wczoraj rano męczyłem się nad koncepcją listu do Rudolfa Bauera, bo krytyki odmówiłem od razu na początku. Ograniczę się do zwrócenia mu uwagi, że całe jego nastawienie wobec wojny, z którego wyrosła ta ,praca”, nie jest w najmniejszym stopniu moim nastawieniem. $Z$ takimi ludźmi nie można się porozumieć w żadnej sprawie. Nawet w zewnętrznych sprawach życia rodzinnego. Po co opowiada mi w dołączonym do manuskryptu, napisanym w niezwykle słabym języku liście o codziennej modlitwie swojego czteroletniego synka (oczywiście znowu grając na uczuciach): Ojcze niebieski, chroń tatusia - ach jakie to czarujące, jakie uczuciowe... (23.04.1917).

Pod wpływem Karla Krausa i Sørena Kierkegaarda Ebner zwraca się przeciw dominującej w życiu publicznym formie rozważania podstawowych pytań ludzkiego życia. W upadku języka, widocznym dla niego głównie w literaturze i w prasie, dopatrywał się powodu ,zmierzchu Europy”. Nawet pisarzom takiego formatu jak Thomas Mann nie szczędził krytyki: 
Ach, cały ten felietonizm jest intelektualnym (duchowym) gadulstwem, zaś o co chodzi z gaduła, o tym poczytaj u Kierkegaarda w Krytyce współczesno$s ́ c i$. Fragment stamtąd już $\mathrm{Ci}$ przeczytałem, ale jest tam dużo innych, równie wybornych rzeczy. A Thomas Mann też nie siedzi cicho i gada o śnie - jak Wilhelm Stekel. Ten jednak jest tym ,głębokim”, wszystko rozumiejącym psychologiem, który „przejrzał” potrzebę snu człowieka duchowego (intelektualnego) (=neurotyka). Zaś Tomasz Mann gada tylko przed siebie jak ,poeta” (jak, nie ,jako”!!) o Indiach (po niemiecku: „Mój spokój chcę mieć”) i o pragnieniu nirwany („Mój spokój za wszelką cenę”). Pewnie, że trudno powiedzieć coś mądrego o śnie, podobnie jak i o śmierci. Spać jest dużo łatwiej, zaś powiedzieć coś trafnego o śnie mogłoby ostatecznie oznaczać, że odmawiamy człowiekowi prawa do spania - a już na pewno nie można dobrze spać i jednocześnie uprawiać naukę o śnie. Być może między spaniem a pisaniem felietonów nie ma aż takiej sprzeczności, a w każdym razie dają się one pogodzić lepiej niż spanie i myślenie o spaniu. Teraz jednak chciałbym - z całą powagą i nie mówiąc tego jedynie, by dostarczyć Ci usprawiedliwiającego Cię moralnie argumentu wobec naszej wspólnej przyjaciółki - przeczytać jednak jeszcze raz tę słynną nowelę Th. Manna o śmierci w Wenecji. Już pierwsza lektura dokonała się, przy całym szacunku a nawet podziwie dla jej stylistycznej i wszelkiej innej techniki, nie bez ,zastrzeżeń”. U mnie wszystko idzie powoli, ale wydaje mi się, że gdy przeczytam Śmierć $w$ Wenecji jeszcze raz, będę miał ostateczne zdanie o niej i o Tomaszu Mannie (26.07.1915).

Według Ebnera w sposób najbardziej wyraźny objawiał się ten „demon naszych czasów" w publikacjach, które poświęcone były chrześcijaństwu i w których dawało się zauważyć skłonność elit intelektualnych do z jednej strony dystansowania się od chrześcijaństwa jako konsekwencję oświecenia i postępu nauk przyrodniczych, z drugiej zaś do intensywnego zajmowania się nim i jego Założycielem - co zdaniem Ebnera musiało z konieczności prowadzić do całkowitego nieporozumienia. I tak da się zrozumieć jego oburzenie, gdy czytał w prasie następujące porównanie:

Znów napisałem coś w zeszycie przeznaczonym dla Ciebie. Tym razem byłem w odpowiednim nastroju, by umieścić tam moje odrzucenie antyfeminizmu. Oczywiście, mój najmocniejszy argument przeciw niemu nie został przedstawiony w tym zeszycie. Jest zresztą zbyt osobistej natury. Jesteś nim mianowicie Ty sama. Cytat z pamiętnika. To się chyba w historii tego świata nigdy nie zmieni, że człowiek zostaje przez ludzi na nim żyjących uwiedziony do wciąż nowej nienawiści wobec ludzi - można sobie powtarzać dowolnie często, że nie wol- 
no się dać do niej uwodzić - i do antysemityzmu. Trudno jest być człowiekiem z tymi ludźmi, ale jeszcze trudniej nie być antysemitą. Dlaczego miałoby się mieć coś przeciwko komuś, kto nazywa się Theodor Keer? Jest on oczywiście Żydem. Ale dlaczego miałoby się mieć coś przeciwko temu? Tymczasem pisze on artykuł w gazecie i wciska w jednym zdaniu długim na kilka linijek tyle potworności, mówiąc dosłownie, że gdy czyta się to w druku i wyobraża sobie, że żyjemy w czasach, gdy coś takiego bez żadnego protestu może być czytane przez tysiące, staje nam wyraźnie przed oczami, że Europa upada. W artykule z okazji osiemdziesiątych urodzin Josefa Poppera (Lynkeusa) w N.W.J. czytam na zakończenie: „żydzi mogą być dumni, że wydali na świat takich geniuszy socjalno-etycznych jak Jezus, Lassalle, Marx ... Popper ... przewyższa jednak tych wymienionych, choćby byli nie wiem jak znaczący w innych dziedzinach - jako prawodawcy, porywający idealiści, agitatorzy, teoretycy - przewyższa on ich pod względem ogólnej ważności i praktycznej stosowalności jego krystalicznie jasnych idei" - - - czy można czuć się spokojnie w świecie, w którym coś takiego może zostać pomyślane, napisane, wydrukowane? Ale słowa o duchu nie brano tak naprawdę nigdy na poważnie. A teraz - widzimy jak chaos „,hichocze”. Umieścić Jezusa między Mojżeszem a teoretykami socjaldemokracji - to nawet nie jest szczególnie oryginalne. Widzieć w nim porywającego idealistę to najwygodniejszy sposób ominięcia zgorszenia, jakie oznacza jego egzystencja w świecie. Ale uważać, że przewyższa go Josef Popper - to jest właśnie „chichot chaosu”. Ale nie - nawet coś takiego nie może uwieść mnie do antysemityzmu (21.02.1917).

Antyfeminizm i antysemityzm są tematami, którymi Ebner zajmuje się obszernie we Fragmentach (przede wszystkim we Fragmencie 16, tzw. Fragmencie o Weiningerze). Powyższe miejsce z listu pokazuje, że Ebner był dzieckiem swoich czasów i zajmował się ideologiami, które ukształtowały początek XX wieku. Pokazuje ono też, jak mocny był ich wpływ na życie intelektualne i jak trudno było Ebnerowi sformułować stanowisko im przeciwne. Przed odrzuceniem przez Ebnera antyfeminizmu i antysemityzmu w jego tekstach można znaleźć zdania, w których wyczuwa się pewną sympatię do tych idei. Dopiero dzięki spotkaniom z konkretnymi „kontrargumentami”, jak na przykład Luiza Karpischek, był on w stanie się od nich odwrócić.

Podobnie rozdwojony był stosunek Ebnera do przyrody i jej piękna. W Gablitz, położonym na granicy regionu Wienerwald, miał on częste okazje, by w czasie spacerów odczuwać czar tego, co ,nie ręką ludzką uczynione". Spokój i odosobnienie możliwe w lasach były dla niego szczególnym błogosławieństwem, mógł bowiem w ten sposób odpocząć od uciążliwego 
kontaktu z innymi ludźmi, na który był nieustannie wystawiony jako nauczyciel w szkole podstawowej. Jako przykład wybrany spośród wielu niech posłuży cytat z listu napisanego w maju 1917 roku:

A potem odbyłem spacer, właściwie to pierwszy spacer w tym roku. Na skraju lasu w kierunku Mauerbach, skąd można zobaczyć drugą stronę doliny - jedno z najpiękniejszych miejsc w naszej okolicy - usiadłem na ławce, by odpocząć i odpocząłem. Dosłownie, wewnętrznie i zewnętrznie. Wieś leży dokładnie przed Tobą - tak jak wiele rzeczy na tym świecie wygląda z zewnątrz pięknie, tyle że nie wolno zawierać z nimi bliższej znajomości - domy w Hochbuch pomiędzy leżącymi za nimi ogrodami a w tle jeden z owych ciągów wzgórz naszego Wienerwaldu ze swymi nieskończenie łagodnymi, spokojnymi i kojąco zarysowanymi liniami, za którymi biegnąc, samo oko, oko a wraz z nim niespokojny człowiek wewnętrzny staje się cichy i zadowolony, nieskończenie spokojny - lasy w pierwszym powiewie wiosennej zieleni, a przed nimi rozpościerające się daleko płaszczyzny łąk - a nad nimi cichy blask popołudniowego słońca - nie mam innych słów na określenie tego, co mnie tam przez godzinę wypełniało, gdy siedziałem na ławeczce, paliłem cygaro, pozwalałem myślom odpływać a oczom wypoczywać na krajobrazie, nie mam innego słowa jak spokój. To prawda - natura może znaczyć dla mnie wiele, bardzo wiele, nie doświadczyłem tego być może nigdy w sposób tak czysty i wyraźny jak tego wieczora - czy jest to ta sama natura, przez którą czuję się często tak umęczony i udręczony, ja, który prawie nie mogę czuć się inaczej niż jako jej pasierb, ciągle w sprzeczności z nią i w sporze z nią, czy to ta sama natura? Czy nie jest to raczej już jakaś natura „zrodzona z ducha”? Ciaggle powraca do mnie myśl, że przeżycie piękna musi być jednak duchowym wydarzeniem w człowieku. Byłyby więc ich trzy - pamiętasz to miejsce w niebieskim zeszycie? Gdy mówię o duchu, biorę to słowo zawsze $w$ bardzo poważnym znaczeniu. $Z$ pewnością istnieje jakaś radość życia zrodzona $\mathrm{z}$ natury - lecz jest także zrodzona $\mathrm{z}$ ducha radość z faktu, że żyję. I być może ta radość zrodzona z natury musi - aby właśnie ta duchowa wypełniła człowieka i tak pozwoliła całej jego egzystencji włączyć się w ducha - najpierw zostać złamana. Być może w głębi wszelkiego przeżycia piękna leży złamanie życia i złamanie naturalnej radości życia. Ta myśl obecna jest we mnie nie od dziś. Owego wiosennego wieczoru, który wywarł na mnie tak mocne wrażenie, przez ową godzinę, gdy siedziałem tak na skraju lasu, nie zniósłbym chyba bliskości człowieka - na szczęście siedziałem w wystarczającym od nich oddaleniu - jedynie Ty musiałabyś siedzieć obok mnie. Wziąłem ze sobą także książkę, ale poprzestałem na przeczytaniu paru mało artystycznych wersów. Parę wersów, które chcę Ci przekazać. Pochodzą 
one z książki pewnego flamandzkiego mistyka z trzynastego wieku - o której, przynajmniej obecnie, nie wiem, co mam myśleć, gdy chodzi o gospodarowanie moim własnym życiem duchowym - i brzmią:

Zajmować się światem zewnętrznym to zaniedbać prawdziwego człowieka. Kto oddaje się zmysłom zewnętrznym, nie znajduje smaku w życiu wewnętrznym. Od zewnątrz ociężały i niegotowy, od wewnątrz zdziczały w miłości i cierpieniu, nie są to co prawda grzechy śmiertelne, ale oddalają człowieka od jego głębokich fundamentów.

Jak Ci się to podoba? Gdy około wpół do ósmej podniósł się wieczorny wiatr i zaczął głaskać (mą twarz) wiejąc dość zimno w kierunku doliny, wyruszyłem w drogę powrotna, tzn. poszedłem do Klebla, gdzie cieszyłem się bardzo tym, że akurat tego dnia jestem przy kolacji sam (9.05.1917).

Mimo korzystnego wpływu, jaki przyroda miała na jego nastrój, także i w tym liście ujawnia się fakt, że stosunek Ebnera do natury nie był niezakłócony, lecz był - jak pisze on sam - ,złamany”. Faktycznie, w myśli podstawowej jego ,pneumatologii” natura nie odgrywa żadnej roli. Jako że wydarzenia natury nie mają zdolności do wypowiedzenia się w słowach, są one dla konstytuowania się Ja jako realności duchowej bez znaczenia. Jeśli przeżycie piękna jak w mistyce zostaje zinterpretowane jako przeżycie Boga, oznacza to niezrozumienie tego, co religijne, a w szczególności chrześcijaństwa. W rozmowie człowieka z Bogiem nie ma miejsca ani na naturę, ani na jej piękno:

Czy mówiąc o „przeżywaniu Boga” i „oglądaniu Boga” mistycy nie stosują błędnie wyrażeń „przeżywać” i „oglądać”? Czy Bóg może być przeżywany, oglądany? Oglądany jest zawsze tylko świat, zaś człowiek przez swój „ogląd świata" nigdy nie zdobędzie - choćby był genialny i wnikliwy - realnej relacji do Boga. Przeżywany jest też zawsze tylko świat, piękno natury, a także człowiek. Twierdzenie, że w przeżyciu piękna, choćby poruszało nas ono głęboko czy też raczej uspokajało nasz niepokój ducha, przeżywany jest Bóg, jest poetycko-estetycznym nieporozumieniem i samo w sobie jest niereligijne ${ }^{3}$.

${ }^{3}$ Ferdinand Ebner, Stowo i realności duchowe. Fragmenty pneumatologiczne (Warszawa: IFIS PAN, 2006), 176. 
Jako że listy zapewniają wgląd w osobiste życie Autora, są one w przypadku Ferdinanda Ebnera świetnym i ze względu na odstęp czasowy jedynym źródłem biograficznym. Gdy chodzi o ocenę filozofii Ebnera (której nie nazywał on jednak filozofią lecz ,pneumatologią”), są one mostem pomiędzy sprawiającymi abstrakcyjne wrażenie rozważaniami we Fragmentach a konkretnymi przeżyciami, które doprowadziły Ebnera do jego przemyśleń. Jako baza empiryczna (słowo „empiryczna” rozumiane w sensie dosłownym) stanowią one razem $\mathrm{z}$ nowym podejściem od strony ukazującego się $\mathrm{w}$ mowie stosunku Ja do Ty i z uwzględnieniem filozoficznej historii problemu tę triadę, która czyni „pneumatologię” Ebnera tym, czym powinna być filozofia:

Myśleć jakąś myśl i wprowadzić myśl w czyn, to są dwie różne rzeczy. I nie wystarcza najwyraźniej to, że jakaś myśl jest po prostu myślana - tu nie leży jeszcze jej właściwa doskonałość, dojrzałość owego twórczego procesu w człowieku, przez którego jest ona myślana, tu nie leży jeszcze jej pełna i cała rzeczywistość, która nie jest w żadnym razie rzeczywistością jej jednorazowego bycia-myślaną w człowieku - musi ona zostać wprowadzona w czyn także w świecie, w życiu i przede wszystkim oczywiście w życiu duchowym człowieka. To, że jest ona najpierw po prostu myślana, opiera się na procesie twórczym, w ramach przebiegu „życia przedstawień” tego człowieka, który ją myśli. To, że wprowadzona zostaje także w czyn, opiera się zaś na tym, że u jej podstaw leży od samego początku właściwy stosunek Ja w myślącym do Ty w ludzkości, w której czyn ten ma miejsce. Moment psychologiczny i moment ściśle duchowy w powstawaniu danej myśli. Wszystkie myśli zrodzone czysto psychologicznie są martwe, bowiem myśl czerpie swą żywotność, polegającą właśnie na tym, że wprowadzona zostaje w czyn, właśnie z jej początku w owym duchowym momencie jej powstania. Czyż nie jest rzeczą możliwą, że ktoś myśli co prawda jakąś wielką myśl, być może nawet myśl, której przeznaczeniem byłoby zrewolucjonizowanie całego życia duchowego ludzkości poczynając od jego podstawy, ale tenże człowiek nie jest jednocześnie w stanie wprowadzić tej rewolucyjnej myśli w czyn? Jest to najwyraźniej możliwe. Pozostaje rzeczą dziwną, że taka myśl zostaje przez człowieka co prawda pomyślana, ale nie zostaje przez niego wprowadzona w czyn. Ten jednak, w kim taka myśl zostaje wprowadzona w czyn, działając na ludzi i na życie duchowe ludzi, musiał ją przecież z pewnością myśleć także twórczo w sobie. Żywa myśl, zrodzona z żywego stosunku Ja w tym, kto ją myśli, do Ty w ludziach, tworzy nowe życie. W myśli martwej, na której początku stoi także niepowodzenie tego stosunku Ja do Ty - i dlatego też w jej powstawaniu mają udział przede wszystkim momenty psychologiczne - życie duchowe w jakiś sposób się za- 
trzymuje. Osiaga ono w niej martwy punkt. Żywa myśl łączy ludzi, martwa dzieli ich, wsuwa między nich ,chiński mur” indywidualnej egzystencji. Życie Ja istnieje w relacji do jego Ty, jego śmierć zaś w niepowodzeniu tej relacji. Tylko z żywego Ja mogą powstawać żywe myśli, takie, które są przez danego człowieka nie tylko myślane, lecz także wprowadzone w czyn. Umierające Ja rodzi martwe myśli. Myśl, która nie ma w sobie konsekwencji innych niż „logiczne”, jest myślą martwą, zrodzoną z umierającego Ja. Każda prawdziwie żywa myśl kpi niejako z praw logiki. (Czyż logika nie opiera się na „samoustanowieniu Ja”, na zasadzie identyczności?) Jej ,życie” na którym opiera się to, że myśl zawiera w sobie nie tylko logiczne konsekwencje, czerpie ona z życia duchowego Ja. To ostatnie nie polega jednak na samoustanowieniu Ja, lecz na ustanowieniu Ty w Ja (Dziennik, 10.07.1917)4.

tlum. Krzysztof Skorulski

\section{The Thought, Written, and Spoken Word. Ferdinand Ebner as the Author of the Letters to Luisa Karpischek (Summary)}

When we are talking about the word in a scientific context, we usually have in mind an abstract and impersonal word proper to the sciences. However, each word, even when used in philosophy, if it is to have any meaning at all, should be connected to life, and particularly, addressed from a concrete I to a concrete Thou. This is how Ferdinand Ebner, one of the founders of the philosophy of dialogue, perceives it. In this article, on the basis of what Ebner wrote to his female friend, Luisa Karpischek, an attempt is made to follow the movement of the word: from the word experienced, thought, and written in the letters and notes, to the word spoken. This is, so to speak, an attempt to show the genesis of Ebner's views, known from his philosophical books. As in life, not everything has been said in the letters, some things remain for the reader to guess.

Key words: Ferdinand Ebner; the philosophy of dialogue; correspondence; the word; the First World War.

\footnotetext{
${ }^{4}$ Ferdinand Ebner, Tagebuch 1917 (Wien: LIT, 2011), 128.
} 


\section{Słowo myślane, pisane i mówione. Ferdinand Ebner w swoich listach do Luizy Karpischek (Streszczenie)}

Kiedy mówimy w kontekście naukowym o słowie, mamy zazwyczaj na myśli abstrakcyjne i bezosobowe słowo nauk ścisłych. Tymczasem każde słowo, funkcjonujące także w dziedzinie filozofii, jeśli ma mieć jakiekolwiek znaczenie, powinno mieć swoje powiązanie z życiem, a dokładniej, powinno być skierowane od konkretnego Ja do konkretnego Ty. Tak przynajmniej widzi to Ferdinand Ebner, jeden z twórców filozofii dialogu. W niniejszym artykule podjęta zostaje, na przykładzie listów Ebnera do jego przyjaciółki, Luizy Karpischek, próba prześledzenia ruchu słowa: pomiędzy słowem przeżywanym, myślanym, zapisywanym w listach i notatkach oraz wypowiadanym. Jest to, można by powiedzieć, swoista próba pokazania genezy poglądów „dialogika” znanych z książek filozoficznych. Tak jak w życiu, nie wszystko w listach zostało dopowiedziane, niektórych rzeczy czytelnik musi się domyślać.

Słowa kluczowe: Ferdinand Ebner; filozofia dialogu; korespondencja; słowo; I wojna światowa.

\section{Bibliografia}

Ebner, Ferdinand. Schriften, t. 2, wyd. Franz Seyr. München: Kösel, 1963.

Ebner, Ferdinand. Mühlauer Tagebuch 23.7.-28.8.1920, wyd. Richard Hörmann, Monika Seekirchner. Wien: Böhlau, 2001.

Ebner, Ferdinand. Stowo i realności duchowe. Fragmenty pneumatologiczne, thum. Krzysztof Skorulski. Warszawa: IFIS PAN, 2006.

Ebner, Ferdinand. Tagebuch 1917, wyd. Marcus Flatscher, Richard Hörmann. Wien: LIT, 2011.

Seyr, Franz. „Biographie”. W: Ferdinand Ebner, Schriften, t. 2, wyd. Franz Seyr. München: Kösel, 1963. 